\title{
Study on the Construction Path of Qualifications and Competences for Political Counselors of Higher Education Institutions
}

\author{
Baicai Chen \\ Yangtze Normal University, Chongqing, China \\ Email: cbcyznu@126.com
}

How to cite this paper: Chen, B. C. (2022). Study on the Construction Path of Qualifications and Competences for Political Counselors of Higher Education Institutions. Open Journal of Social Sciences, 10, 163-169.

https://doi.org/10.4236/jss.2022.101014

Received: December 20, 2021

Accepted: January 14, 2022

Published: January 17, 2022

Copyright $\odot 2022$ by author(s) and Scientific Research Publishing Inc. This work is licensed under the Creative Commons Attribution International License (CC BY 4.0).

http://creativecommons.org/licenses/by/4.0/

\begin{abstract}
Political counselors of higher education institutions are the front-line personnel in charge of students' affairs. They are direct promoters and executors of educational policies, whose qualifications and competences have a direct effect on the effectiveness of education, the quality of talents and the stable development of colleges and universities. To help effectively carry out ideological and political in higher education institutions, this paper aims to discuss the ways in which political counselors become qualified and competent from perspectives of political quality, professional conduct, psychological quality and comprehensive competence.
\end{abstract}

\section{Keywords}

Political Counselor, Qualification, Competence, Higher Education Institutions

\section{Introduction}

Since the $18^{\text {th }}$ National Congress of the Communist Party of China, the Party Central Committee has attached great importance to the ideological construction of colleges and universities, pointing out that the fundamental task of education is to establish morality and cultivate people, and to make it clear who, how and for whom to cultivate talents. To effectively carry out ideological and political education in colleges and universities, it is not enough to rely solely on the classroom's theory teaching, which also requires the cooperation of ideological and political counselors (Li, 2014). Political counselors are the backbones of ideological and political education for college students (Shi, 2009). They are college students' advisers in learning and friends in life, with whom students engage 
the most on campus. Their words and deeds have a subtle influence on students (Yuan \& Zeng, 2017). Therefore, the qualifications and competences of a university counselor have a direct effect on the effectiveness of education, the quality of talents and the stable development of universities. In view of this, it would be a must for colleges and universities to maintain a high-quality and highly capable counselor team featuring high political consciousness, good professional conducts, excellent psychological qualifications, and strong comprehensive abilities. This paper first discusses the significance of political counselors, and then investigates what qualifications and competences a political counselor should have, and lastly provides ways for political counselors to accomplish these qualifications and competences.

\section{Significance of Political Counselors}

Political counselors play a vital role in higher education institutions, which explains why all colleges and universities in China attach the highest priority to the team. Therefore, before we explore what qualifications and competences a political counselor should have, we will discuss the significance of political counselors.

\subsection{The Staunch Supporters of Socialist Education in Higher Education Institutions}

It is the fundamental task of higher education institutions to train builders and successors through socialist education for the socialist cause who are both socialist-minded and professionally competent (Liu et al., 2021). Thus, the institutions must help students to develop a strong socialist belief that can resist the invasion of hostile ideologies and forces on the basis of actual needs of the socialist cause with Chinese characteristics, and in accordance with the socialist education policies of the Communist Party of China and the socialist core values. This whole cause is based on the ideological and political guidance by the political counselors since they are the teachers whom students engage the most on campus and have the greatest influence on the latter. Competent political counselors inculcate the socialist core values in a subtle way during the engagement with students, whereby they are staunch supporters for higher education institutions to cultivate qualified socialist talents.

\subsection{The Guide of College Students for Healthy Growth}

College students are around the age of twenty and in a period of immaturity in thought (Naomi et al., 2015). Therefore, they are not mature enough in ideology, knowledge foundation, or judgment. They are still developing their views of life, world and values. In this period, they are abruptly put in front of many new affairs, but they have not developed the skills or competences needed. Without right guidance, they might end up in a bad situation. Political counselors are professional teachers to handle students' affairs. Being experienced in this field, they may give the students proper guidance on healthy development. 


\subsection{The Protectors of Campus Safety and Stability}

The safety and stability on campus really matter in the school development (He \& Mi, 2005). University campuses are open to the public and packed with different people. Students have closer contact with the outside world, hence in a more complex situation than in middle schools. In such a situation, university campuses have become major targets of domestic and foreign hostile forces, and they are easily shocked by cases of social inequality and international hot issues, all of which are likely to become instability factors on campus. Being directly responsible for educating and managing college students, political counselors have countless ties with students. In daily work, they remind the students of what to do and what not do. In emergencies, they are always the first to show up and control the situation. They are major protectors of the campus stability at higher education institutions.

\section{Qualifications and Competences for Political Counselors}

\subsection{Good Political Quality}

The word political quality is a general term of political orientation, political stand, political acuity, political quality, political integrity and ideological style. And it is also an important reflection of outlooks on life, value and world (Li, 2010). As the backbone of ideological and political education for college students, political counselors shoulder the important responsibilities for training qualified builders for the country and develop college students into successors, which should highly agree to socialism of Chinese characteristics. Therefore, they should have good political quality for the first place. With the reform of the market economic system in China, college students are developing towards different directions in terms of political thoughts, beliefs and feelings. As the mainstream in charge of ideological and political guidance to college students, political counselors should apply their profound political theoretical knowledge to pointing the right way for the students, in order to help them make the right judgment and avoid ideological mistakes. University political counselors themselves should become strong believers of the lofty ideal of communism and the common ideal of socialism with Chinese characteristics. They must have a clear political stand. They should identify with the path of socialism with Chinese characteristics and resolutely implement the Party's plans, principles and policies by carefully learning the theories, plans, principles and policies of the Party. They should be politically clearheaded in any situation and closely follow the footsteps of the Party Central Committee. Only with good political quality could political counselors effectively help the students cultivate the right political stand and spiritual belief, raise the political acuity, and develop high political qualities, the strong sense of social responsibilities and good political integrity.

\subsection{Excellent Professional Conducts}

As the social transformation accelerates in the era of networking and informa- 
tion application, higher education institutions are not just secluded ivory towers anymore. Students nowadays are widely informed, strong in their senses of self and rights, and advanced in thoughts. Administrative measures alone do not work in treating students' affairs anymore. Being a model is better than mere oral instruction. To well manage and educate students ideologically, university political counselors must themselves become good models of moral cultivation and political consciousness and apply their own personal charisma to influence and inspire students. Political counselors' professional conducts and morality have a direct impact on college students. When educating students, political counselors must be students' models in abiding by laws, regulations and teachers' ethics. They should treat all students equally and serve and help them wholeheartedly. Just as Confucius says, "If the ruler is personally upright, all will go well even though he does not give orders; but if he is not personally upright, even though he gives orders, they will not be obeyed." Only with good professional conducts could political counselors win students' recognition and smoothly proceed with the work. Therefore, political counselors should be clear about the close relationship between their work and talent training, improve their professional conducts, and avoid inconsistency between words and deeds or unfair treatment to students. They should inspire and educate students with their personal charisma and noble morality.

\subsection{Good Psychological Quality}

The political counselors' psychological quality has a direct impact on students' mood and their psychological quality development. Political counselors with good psychological quality could make more accurate and better decisions based on competences accumulated in daily work, and they could have the problem solved quickly in emergencies. Political counselors without sound psychological status could neither develop their comprehensive competences nor train healthy and well-managed students. Political counselors should be able to handle miscellaneous affairs, great work pressure, and even student disputes. They would also face many objective issues which could not be solved by themselves, all causing them great psychological pressure. In daily work, they might be needed by college students for solving psychological problems, which otherwise results in more psychological problems for the latter, especially in present days when causes of psychological problems increase. According to Lu (2020), a large proportion of college students are in a sub-health status psychologically. Faced with such a group of service objects, political counselors must have the necessary psychological counseling knowledge and psychotherapy methods. It also demands that political counselors follow the scientific mental activity laws, enhance psychological endurance, and develop positive and stable personalities, strong will, and right motivations and conducts. Only with a positive and healthy mindset could they successfully deal with all kinds of pressure, duly solve psychological problems, and reasonably apply the psychological defense 
mechanism to prevent psychological illness. Only in such a way could they develop high-quality talents who meet the needs of society.

\subsection{Strong Comprehensive Competences}

Political counselors are faced with students who are different in thousands of ways from their own characteristics. Today's college students are characterized by extensive knowledge, agile thinking, unique personalities, and an open mind to new things. The advanced internet offers them an easy access to information of any kind. If political counselors cannot meet students' needs with their own knowledge base, they might fall into a passive situation, which has a negative impact on their future careers. Political counselors are required to have both professional knowledge and social experiences to handle all kinds of emergencies and deal with various scenarios. Besides having such abilities as communication, coordination, scientific research, organization, management, self-adjustment, etc., a qualified political counselor also needs to master the internet skills and keep improving their own learning capacity. Therefore, political counselors can be said to be a multi-dimensional complex and a combination of many abilities. In a word, as society develops fast and the environment evolves dramatically, political counselors should master more working competences. Only when they always bear in mind their responsibilities, constantly strengthen learning and strive to improve their own quality, can they meet the needs of the development of higher education and do a better job in education and management.

\section{Ways for Political Counselors to Develop Qualities and Competences}

\subsection{Consolidating Political Stand and Being Active Learners}

Being responsible for training qualified successors to the socialist modernization of the country, political counselors must have a firm political stand (Yan, 2017). They should follow the political principles and directions of the Party, and timely understand the development history and current policies of the Party and the central government. They should make the right judgment of situations whether domestic or overseas and devote active efforts to guiding the healthy growth of students. On such a basis, they should be active in and be good at learning to meet the requirements of having "strong political consciousness, good workability, and good discipline and conduct". Only by keeping learning could they consolidate the knowledge foundation and improve the workability. As ideological workers, political counselors should study the outstanding and latest achievements of the Party. They should advance with the times and consolidate the theoretical foundation. As educators and administrators, political counselors should take the initiative to study such disciplines as management, education, sociology so as to master scientific management philosophies and methods, and to optimize the student management approaches in order to achieve a perfect balance between education and management. As service providers for students, 
political counselors should further learn psychology and humanity and social sciences, keep up with the hot topics, learn about the ideological change and needs of college students, and accept students' new concepts so that they can be true guides for the latter.

\subsection{Taking the Initiative in Practice and Summarization}

Practice is the sole criterion for testing truth. Only in practice can we have a deeper understanding of the theoretical knowledge learned, gain a correct perception of things, and be more persuasive and infectious when educating college students (Dirkx, 1998). Only those who have personal experiences in this field could be convincing and inspiring in university student education. Practice includes these qualifications inside and outside the campus. Since political counselors have miscellaneous work to deal with and universities are a relatively secluded place, they need to learn opportunities in practices. Otherwise, they will find it hard to disabuse students of their confusions sometimes, which can negatively impact the effect of ideological and political education. In addition to the social practice of "going to the countryside", counselors should actively integrate into the social environment through volunteer activities, school local cooperation platform, employment and entrepreneurship base, internship and temporary exercise, and make objective summary to form their own knowledge accumulation.

\subsection{Improving the Relevant Systems and Making Reasonable Plans}

To improve political counselors' qualities and competences, supports at the social and school levels and system guarantees are needed. Higher education institutions should fully understand the principles of documents on counselor training, make effective systems, and work out reasonable plans on improving political counselors' qualities and competences. Higher education institutions should improve the counselor training systems and arrange targeted training for them based on their work nature and requirements to develop them into experts at their posts. For assessment systems, on the premise of fairness and equality, these systems should help to supervise and urge political counselors to maintain strong senses of responsibility and mission, and voluntarily improve their qualities and competences. Incentive systems should give positive impulse. While protecting political counselors' rights and interests, these systems should offer them a development platform and motivate their work enthusiasm.

\section{Conclusion}

The qualifications and competences of political counselors are an important guarantee for the correct development of political thought and ideology in colleges and universities. The qualifications and competences for a good political counselor can be constructed from the aspects of political quality, professional 
conducts, psychological quality and comprehensive ability. To achieve these, they should consolidate political stand and become active learners, and they should take the initiative in practice and summarization. Meanwhile, colleges and universities should improve the relevant systems to offer them a development platform and motivate their work passion.

\section{Conflicts of Interest}

The author declares no conflicts of interest regarding the publication of this paper.

\section{References}

Dirkx, J. M. (1998). Transformative Learning Theory in the Practice of Adult Education: An Overview. PAACE Journal of Lifelong Learning, 7, 1-14.

He, Y. S., \& Mi, B. C. (2005). Foundation of Structuring Harmonious Campus: Safety and Stability. Journal of Hebei University of Environmental Engineering, 3, 139-143.

Li, G. (2014). Analysis on the Functional Role of University Ideological and Political Counselors. The Science Education Article Collects, 6, 8+12.

Li, Y. Z. (2010). Study on the Political Accomplishment Assessment Issue for Cadres. New Heights, 5, 88-92.

Liu, X., Zhao, X., \& Starkey, H. (2021). Ideological and Political Education in Chinese Universities: Structures and Practices. Asia Pacific Journal of Education, 1, 1-13. https://doi.org/10.1080/02188791.2021.1960484

Lu, S. Z. (2020). Research on Relationship between Physical Activity and Body Composition of College Students with Mental Sub-Health. Journal of Occupational Health, 22, 3119-3128.

Naomi, E. S., Goldstein, A. N., Elizabeth, G., Marsha, L., \& Jessica (2015). You're on the Right Track: Using Graduated Response Systems to Address Immaturity of Judgment and Enhance Youths' Capacities to Successfully Complete Probation. Temple Law Review, 88, 803.

Shi, S. L. (2009). Constructing Harmonious Ideological and Political Education Mechanism in Universities of China by Enhancing the Team-Building of Counselors. Journal of Sichuan University of Science \& Engineering (Social Sciences Edition), 4, 117-120.

Yan, Y. (2017). Firm Political Position as the Basic Requirement of College Counselors. Beijing Education (Moral Education), 15, 32-33.

Yuan, W., \& Zeng, Y. (2017). Study of Methods to Improve the Counselors' Scientific Research. Creative Education, 8, 305-311. https://doi.org/10.4236/ce.2017.83024 